\begin{tabular}{c} 
Volume and Issues Obtainable at Center for Sustainability Research and Consultancy \\
Journal of Business and Social Review in Emerging Economies \\
ISSN: 2519-089X (E): 2519-0326 \\
Volume 5: No. 2, December 2019 \\
ᄃSRᄃ \\
Journal homepage: www.publishing.globalcsrc.org/jbsee \\
\hline
\end{tabular}

\title{
Solar Energy in the Logistics Sector: Assessments on Turkey
}

\author{
${ }^{1}$ Ayşegül Taşçioğlu, ${ }^{2}$ Hilal Yildirir Keser \\ ${ }^{1}$ Lecturer, Burdur Mehmet Akif Ersoy University, Burdur, Turkey, atascioglu@mehmetakif.edu.tr \\ ${ }^{2}$ Assoc. Prof. Bursa Technical University, Turkey, hilal.yildirir@btu.edu.tr
}

\begin{tabular}{l} 
ARTICLE DETAILS \\
\hline History \\
Revised format: November 2019 \\
Available Online:December 2019
\end{tabular}

\section{Keywords}

Solar Energy, Logistics, SES, Warehouse Systems

\section{JEL Classification:}

P28,P29

\section{ABSTRACT}

The fact that the current energy production resources have a tendency to be extinguished rapidly, the raw material prices have increased, their negative effects on the environment and human health, some difficulties in their use have increased the studies conducted on new and renewable energy sources in recent years. Among the renewable energy technologies, even though it is somewhat expensive, the easiest technology in terms of design and installation is the photovoltaic technology which is an application of solar energy. But its real superiority arises from the fact that it is a technology that does not pollute the environment, is environmentally friendly and has low maintenance costs. The use of solar energy has increased considerably with the increase in the use of renewable energy sources in the world and our country in recent years and the roofs have had the largest share in this regard. Considering that more than $50 \%$ of the installed facilities in Germany and Italy, which are the starting point of solar energy in Europe, are on the roofs, the roofs have an important place in the increase of solar energy usage. Turkey is in a fortunate situation compared to many countries in terms of the solar energy potential due to its geographical location. South Eastern Anatolia Region is the region that receives the most solar energy, this is followed by the Mediterranean Region. The logistics sector has recently been one of the sectors in which solar energy is widely used in the world and in Turkey. In particular, significant reductions have been achieved in logistics costs with the solar energy systems installed on the roofs of the logistics warehouses, this event has increased the competitiveness of the companies. It is also known that solar energy has been started to be used in transportation activities and there are $\mathrm{R} \& \mathrm{D}$ studies for increasing road vehicles and cargo ships working with solar energy. In addition, efforts are being made to improve the solar-powered highways which strengthen the transport infrastructure and the logistics processes and these applications are becoming widespread. In the study, solar energy which is one of the most interested ones among renewable energy forms and photovoltaic technology producing electrical energy using it will be discussed in this context, and then the current situation in Turkey and the World will be presented. Finally, the usage of solar energy in the logistics sector and the application examples in the world and in Turkey will be included.

(C) 2019 The authors, under a Creative Commons AttributionNonCommercial 4.0 
Assessments on Turkey. Journal of Business and Social Review in Emerging Economies, 5 (2), 225-236

DOI: $10.26710 /$ jbsee.v5i2.822

\section{Introduction}

The fact that the energy prices continuously increase due to the political developments in the world and that the fossil fuels will be consumed away after a certain period of time and that their production is quite expensive makes it necessary to determine the alternative energy resources and make use of these resources in high efficiency. The largely use of non-renewable energy resources in the world has significantly increased environmental problems. Therefore, the tendency towards renewable energy sources with low environmental impact has become advantageous in all respects (Anonymous 2018a). Energy resources are divided into "primary" and "secondary energy resources" in terms of changing or not changing their qualities. Primary energy resources are the resources that can be used without being modified as they are in nature. For example; coal, lignite, oil, natural gas, geothermal energy, hydraulic energy, solar energy, wood, animal and plant residues are this type of energy resources. Secondary energy sources are the types of energy obtained by treating the primary resources through various processes. For example, electric energy, diesel, gasoline, kerosene, etc. are such type of energy resources. The United Nations collects energy resources in two main groups as"renewable" and "non-renewable" energy resources. Renewable energy resources are solar, wind, biomass, water power, wave power, ocean currents, geothermal energy (Figure 1). The non-renewable energy sources are defined as an energy resource in which the substance cannot be reused. Coal, petroleum, natural gas, and uranium are included in this group (Oluklulu 2001).

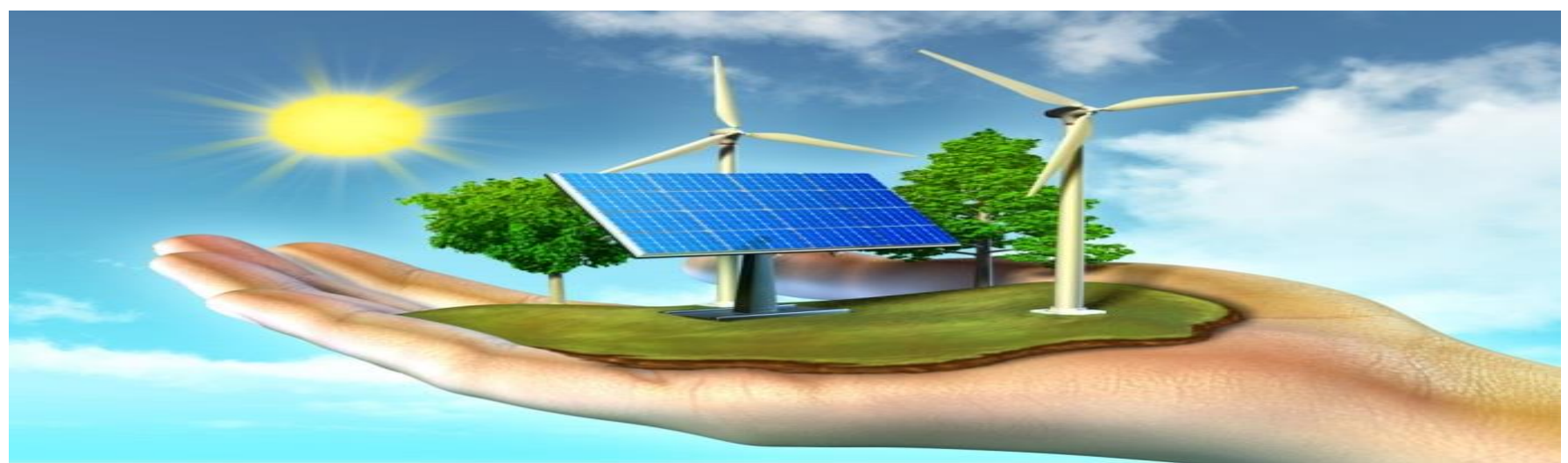

Figure 1. Renewable Energy Resources (Anonymous 2018b).

The fact that the current energy production resources have a tendency to exhaust rapidly, that the raw material prices increase, the negative impacts on the environment and human health, a number of difficulties in their use have increased the studies recently carried out on the new and the renewable energy resources (Özgöçmen 2007). The renewable energy resources are defined as the energy obtained from continuous or repetitive currents in the natural energy cycle, or as the energy flows of which space is filled in the speed at which they are used. (Öztürk and Kaya 2013).

\section{Solar Energy in the World and in Turkey}

\subsection{Solar Energy in the World}

The use of solar energy has increased considerably along with the increase in the use of renewable energy resources in the world and in our country in recent years and the roofs have taken the biggest share in this issue. Considering that more than $50 \%$ of the installed facilities existing at present in Germany and Italy which are the starting point of solar energy in Europe are on the roofs, roofs have an important place in the increase of solar energy usage.

The regions and countries that receive the sunlight the most: a large part of Africa (especially the region known as Sahara Africa, the region which is completely desert), Australia and the middle region of America as the placed where the sun reaches the most are more advantageous than other regions of the world (Map 1a). Turkey having sunlight about 1500 to $2000 \mathrm{kWh}$ on $\mathrm{m} 2$ per year according to the scale on this map draws attention as a country which is far above the average and more advantageous. Almost all of the regions that receive sunlight are composed of deserts, these regions are remote from the residential and investment regions. On the other hand, even if an investment is made here, the transportation of the generated energy will require a second cost. Therefore, countries 
such as Turkey, Spain attract attention as the most advantageous countries of the world when we consider their investment opportunities, consumption centers and similar features.

Countries such as Germany, Denmark, and Spain are the pioneers of solar energy generation and technology in Europe. Germany, which is progressing on the path of becoming a global power, is an important country in the issue of solar energy (Map.1b). Denmark is also surprisingly come forward in the production of solar cells (Anonymous 2018c).

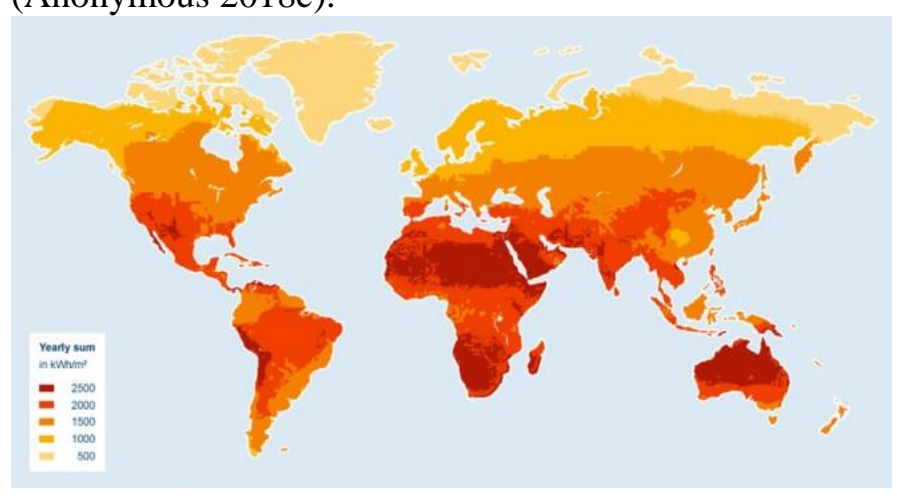

Map 1a. World Sun Light Map

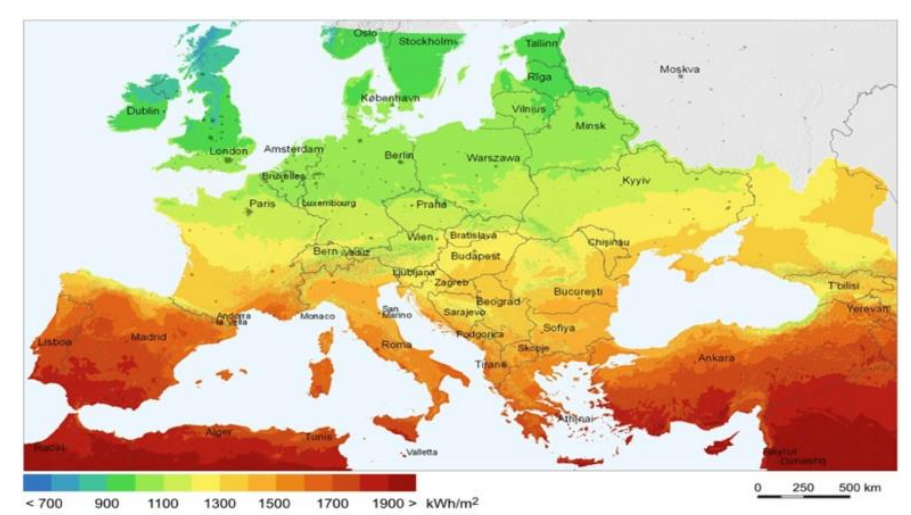

Map 1b. Europe, Middle East and North Africa Radiation Map

Source: Anonymous 2018c

\subsection{Solar Energy in Turkey}

Due to its geographical location, our country is efficient in terms of solar energy potential compared to many countries. (GDRE, 2018). Solar energy is the most important source of natural energy for the countries in the Mediterranean zone, just like our country. Although our country is located in a region which is called as solar zone and rich in solar energy, solar energy is not sufficiently benefited (Öztürk 2008b). In our country, it is unfortunately seen that solar energy is mostly utilized for hot water supply.

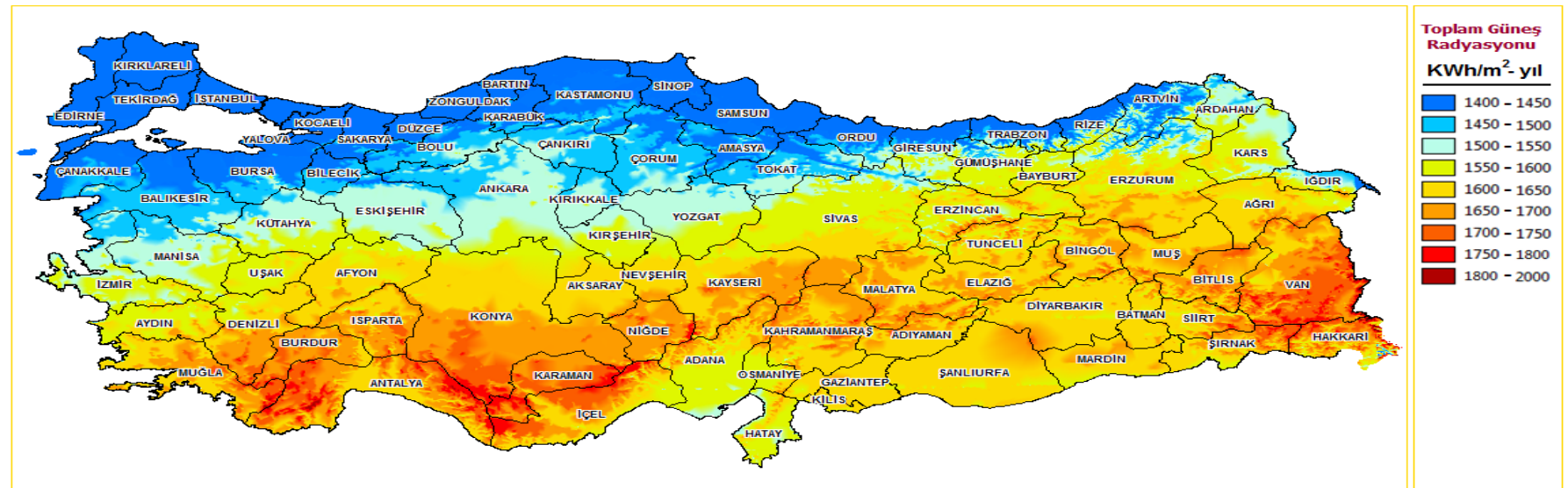

Map 2. The atlas of solar energy potential in Turkey

Source: General Directorate of Renewable Energy (GDRE), 2018

In the study titled "Turkey Solar Energy Potential Atlas" prepared by The General Directorate of Renewable Energy, it has been stated that the amount of solar radiation is between 1400 and $2000 \mathrm{kWh}$, although it shows regional variations (GDRE, 2018). According to another study carried out by GDRE utilizing the data about the sunshine duration and radiation intensity measured in the years of 1966-1982 which is in the General Directorate of State Meteorological Affairs (GDSMA), it has been determined that the average annual sunshine duration of Turkey has been 2640 hours (daily total of 7.2 hours), the average total radiation intensity has been $1311 \mathrm{kWh} / \mathrm{m}^{2}$ year (daily total of $3,6 \mathrm{kWh} / \mathrm{m}^{2}$ ). The monthly solar energy potential of Turkey and sunshine duration values have been given in Table 1 (GDRE, 2018). 
Table 1. Monthly Average Solar Potential Of Turkey

\begin{tabular}{|l|l|l|l|}
\hline MONTHS & $\begin{array}{l}\text { MONTHLY } \\
\text { (Kcal/cm2-month) }\end{array}$ & $\begin{array}{c}\text { TOTAL } \\
\text { (kWh/m2-month) }\end{array}$ & $\begin{array}{l}\text { SUNSHINE } \\
\text { (hour/month) }\end{array}$ \\
\hline JANUARY & 4,45 & 51,75 & 103 \\
\hline FEBRUARY & 5,44 & 63,27 & 115 \\
\hline MARCH & 8,31 & 96,65 & 165 \\
\hline APRIL & 10,51 & 122,23 & 197 \\
\hline MAY & 13,23 & 153,86 & 273 \\
\hline JUNE & 14,51 & 168,75 & 325 \\
\hline JULY & 15,08 & 175,38 & 365 \\
\hline AUGUST & 13,62 & 158,40 & 343 \\
\hline SEPTEMBER & 10,60 & 123,28 & 280 \\
\hline OCTOBER & 7,73 & 89,90 & 214 \\
\hline NOVEMBER & 5,23 & 60,82 & 157 \\
\hline DECEMBER & 4,03 & 46,87 & 103 \\
\hline TOTAL & 112,74 & 1311 & 2640 \\
\hline AVARAGE & 308 cal/cm2-day & $3,6 \mathrm{kWh} / \mathrm{m} 2$-day & 7,2 hour/day \\
\hline
\end{tabular}

Source: GDRE, 2018

The distribution of solar energy potential and sunshine duration values by the regions have been given in Table 2 . Accordingly, the region receiving the most solar energy in Turkey is the South Eastern Anatolian Region, the Mediterranean Coast follows this. However, it has been found out with the studies carried out later that these values are lower than the real potential of Turkey. Since 1992, GDRE and GDSMA have taken solar energy measurements for the purpose of measuring solar energy values in a healthier manner. As a result of the measurement activities in progress, it has been expected that the former values of the solar energy potential of Turkey will come out to be more than 20-25\%. It can be expressed that the data used in the Solar Energy Potential Atlas is more accurate in this framework. (GDRE, 2018).

Table 2. The Distribution of the Total Annual Solar Energy Potential By Regions

\begin{tabular}{|c|c|c|}
\hline REGION & $\begin{array}{l}\text { TOTAL SOLAR ENERGY } \\
\text { (kWh/m2-year) }\end{array}$ & SUNSHINE DURATION （hour/year) \\
\hline $\begin{array}{ll}\text { SOUTH } & \text { EASTERN } \\
\text { ANATOLIA } & \end{array}$ & 1460 & 2993 \\
\hline MEDITERRANEAN & 1390 & 2956 \\
\hline EASTERN ANATOLIA & 1365 & 2664 \\
\hline MIDDLE ANATOLIA & 1314 & 2628 \\
\hline EGEAN & 1304 & 2738 \\
\hline MARMARA & 1168 & 2409 \\
\hline BLACKSEA & 1120 & 1971 \\
\hline
\end{tabular}

Source: GDRE, 2018

\section{Photovoltaic Technology}

All renewable energy resources on the earth are generated by the effect of solar radiation which can be converted directly or indirectly into energy by using different technologies. Although it is the most expensive renewable energy technology, the "photovoltaic" technology is the easiest energy technology in terms of design and installation. But its main superiority arises from the fact that it is a technology that is environmentally friendly and does not pollute the environment and has low maintenance costs (Öztürk and Kaya 2013). The fact that there are no moving parts in this technology and that the system consists of very simple components is also an important advantage. 


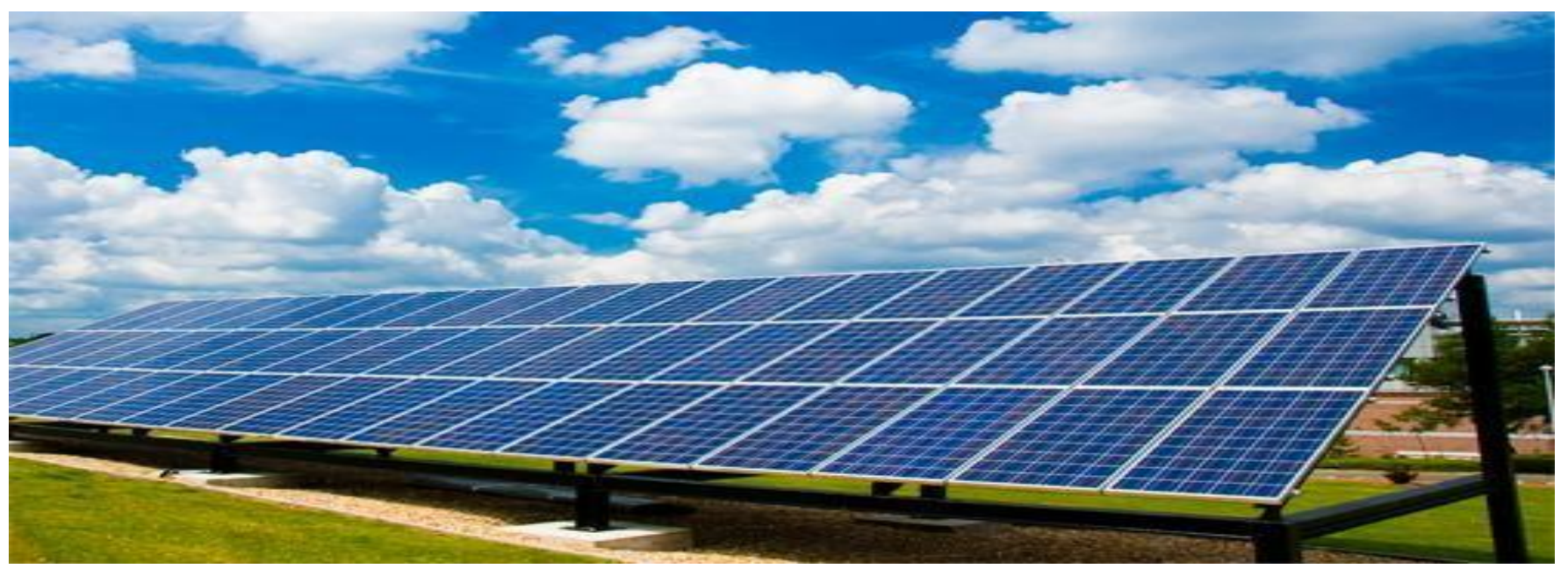

Figure 2. Photovoltaic Solar Panels (Anonymous 2018d)

Photovoltaic is a combination of the words photo which means light in Greek and voltaic meaning tension which is inspired by Alessandra Volt who designed the machine that improves the electric current. Solar cells (photovoltaic cells) were first researched by Becquerel in 1839. Solar cells are designed from semiconductor materials that convert sunlight directly into electricity (Öztürk 2008b). The square, rectangular, circular-shaped solar cells have a surface area around $100 \mathrm{~cm}^{2}$ in general, their thicknesses, especially in the most common silicon solar cells range between 0,20,4 mm (Karamanav 2007). Figure 3 shows the Cell, Panel and Layout views of the Solar Panels.

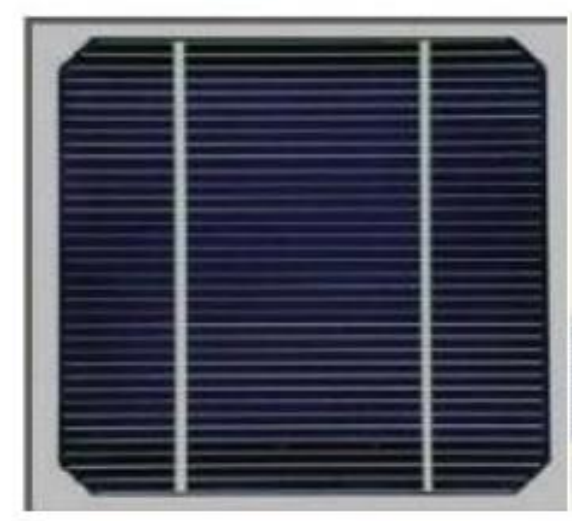

Hücre

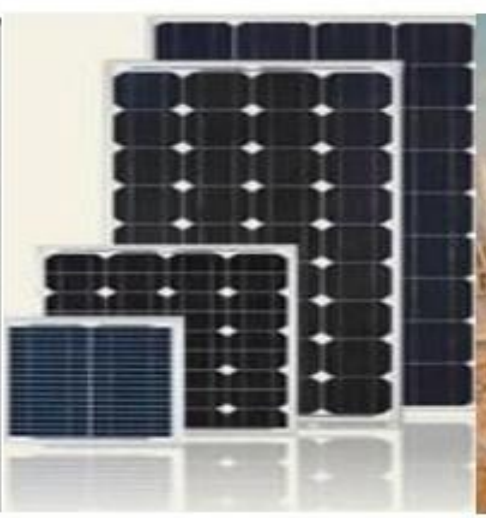

Modül

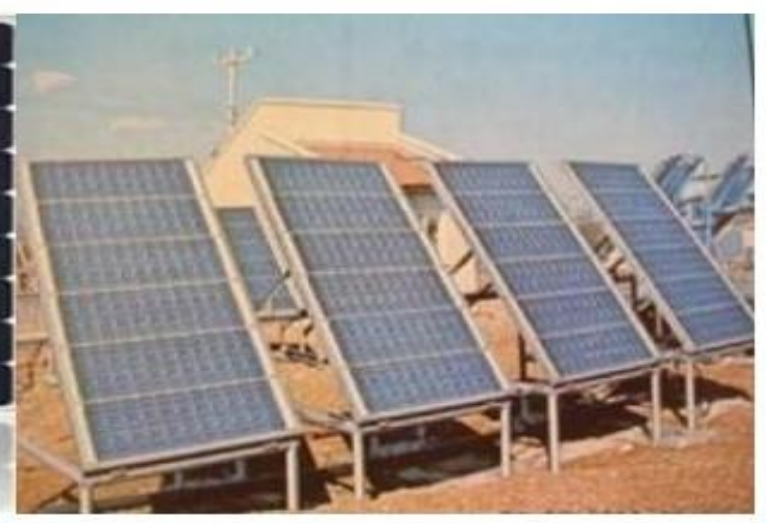

Dizi

\section{$(0.3-2 \mathrm{~W})$}

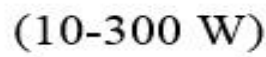

$(>5 \mathrm{MW})$

Figure 3. The Cell, Module (Panel) and Layout views of Solar Cells

Solar cells work based on the photovoltaic principle. That is, when the light falls on them, electrical voltages are formed at their ends. The source of the electrical energy supplied by the cell is the solar energy coming to its surface. Depending on the structure of the solar cell, solar energy can be converted into electrical energy with an efficiency between $5 \%$ and $20 \%$. In order to increase the power output, a great number of solar cells are connected to each other in parallel or series and mounted on a surface. This structure is called a solar panel or photovoltaic panel. Depending on the power demand, the panels are connected in series or parallel to each other and a system is established ranging from a few Watts to Megawatts (Anonymous 2018e).

\section{Solar Energy in the Logistics Sector and Examples of Application}

Logistics; refers to all processes of a product from the first producer to the final consumer such as shipping, storage, customs clearance, packaging, and distribution.

Logistics is the most important cost item of all sectors, primarily as a textile, food, chemistry, chemistry. For this reason, $\mathrm{R} \& \mathrm{D}$ studies are carried out by the companies in to reduce the costs in all logistics services such as storage, customs clearance, and distribution, especially in transportation activities. 
With the reduction of costs in the logistics sector, the green logistics concept has come to the forefront with the desire of keeping the damage given to the environment at a minimum level. Reducing the $\mathrm{CO} 2$ emissions by using renewable energy resources instead of fossil fuels in transportation services has been one of the main objectives of the logistics companies. Solar Energy which is one of the most important renewable energy resources has been used in many areas in the logistics sector.

Solar Energy is one of the most important renewable energy resources that increases efficiency and reduces costs in the Logistics Sector. Solar energy is used extensively in the following logistics service areas;

1. Transportation Services

2. Storage Services

3. Infrastructure services for logistics services

\subsection{Transportation Services}

Solar energy has begun to be used on all of the vehicles in all modes of transportation including mainly highway, airway, maritime and railway. The use of the solar energy systems in transportation services which is one of the logistic services that have the highest damage to the environment is an important opportunity for both minimizing the negative effects on the environment and reducing the costs.

The use of flexible solar modules in highway transportion can be given as examples of solar energy use. By mounting the solar modules on the roofs of the highway transportation vehicles, the batteries are ensured to be ready for continuous use. At the same time, the batteries are prevented from getting overcharged (Taşıyanlar, 2017). The vehicle named Tesla Semi is another example for the use of solar energy in highway transportation in the recent period. This vehicle is introduced as an 18 -wheel trailer making $805 \mathrm{~km}$ with its huge battery charged with solar energy, carrying a load of 17.5 tons and with a height of 2 meters. (NTV, 2017).

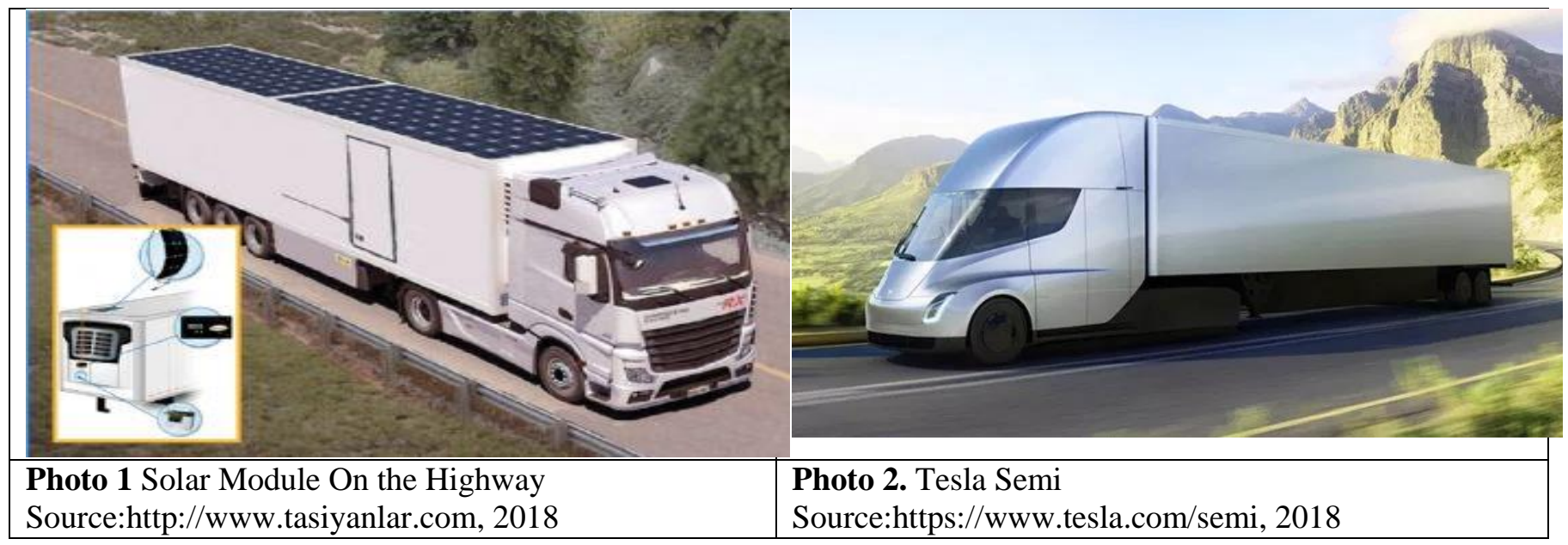

The other mode of transportation in which solar energy is currently being used most intensively is the maritime transportion. The EMERALD ACE which is a Ro-Ro vessel using renewable energy, launched by the Panasonic Company in 2010 together with Mitsui O.S.K. Lines Ltd. (MOL)and Mitsubishi Heavy Industries Ltd.(MHI) is able to generate its own energy with the hybrid electric power when it is anchored, meanwhile, can also prevent carbon emissions by turning off its diesel engines. The high-performance HIT solar modules of Panasonic and (160 KW) and lithium-ion batteries (approx. 2.2MWh) are used onboard to obtain electrical energy. By using the energy generated by HIT solar modules and stored in lithium-ion batteries while the vessel is anchored, the diesel power generators of the vessel can be switched off. And this reduces the environmental impact and carbon emissions of the vessel. (MOL, 2012). 


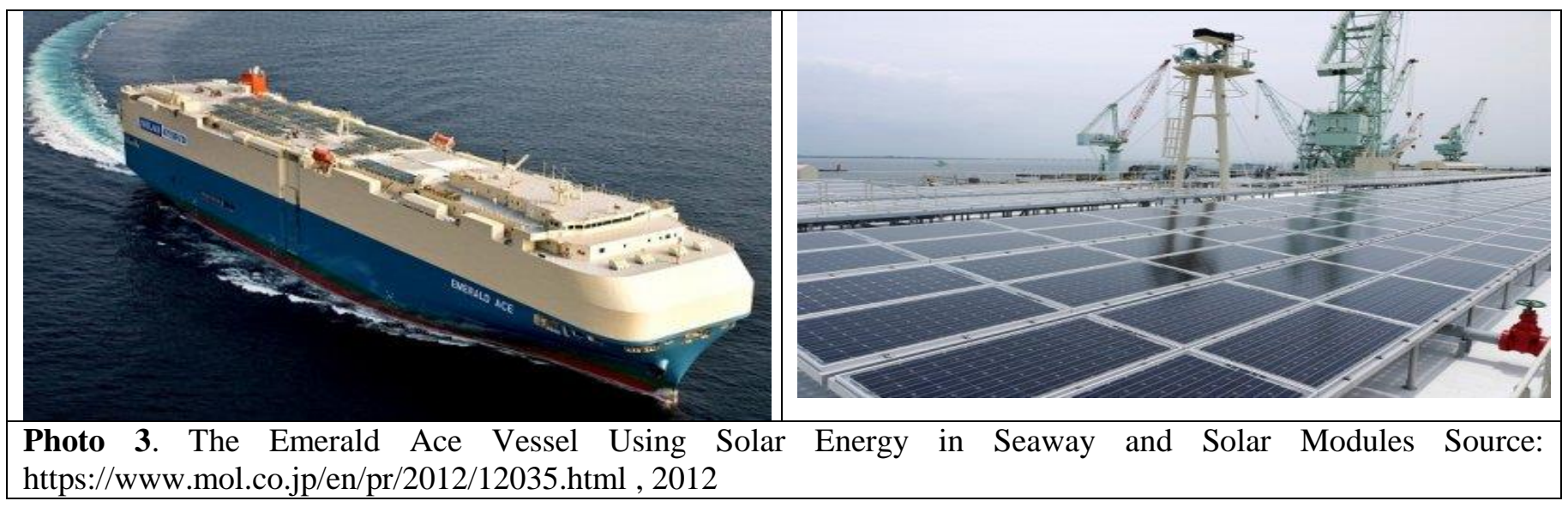

Another mode of transportation in which solar energy is used is a railway transportation. The Indian Railways has started to use solar energy in railway

transportion to reduce the carbon footprint of the trains. Within the scope of the planned new project, by coating the upper part of the train running on the railways with solar panels, it has been intended to produce about $20 \mathrm{kWh}$ that the train requires for the internal need. It has been planned to use the produced energy in the operations of the train such as lighting, door operation, checking passenger information, and also to storing energy in the battery pack of $120 \mathrm{Ah}$. In this way, the operation of the electrical systems of the train at night is made possible without the need for diesel fuel. (ekolojist, 2017).

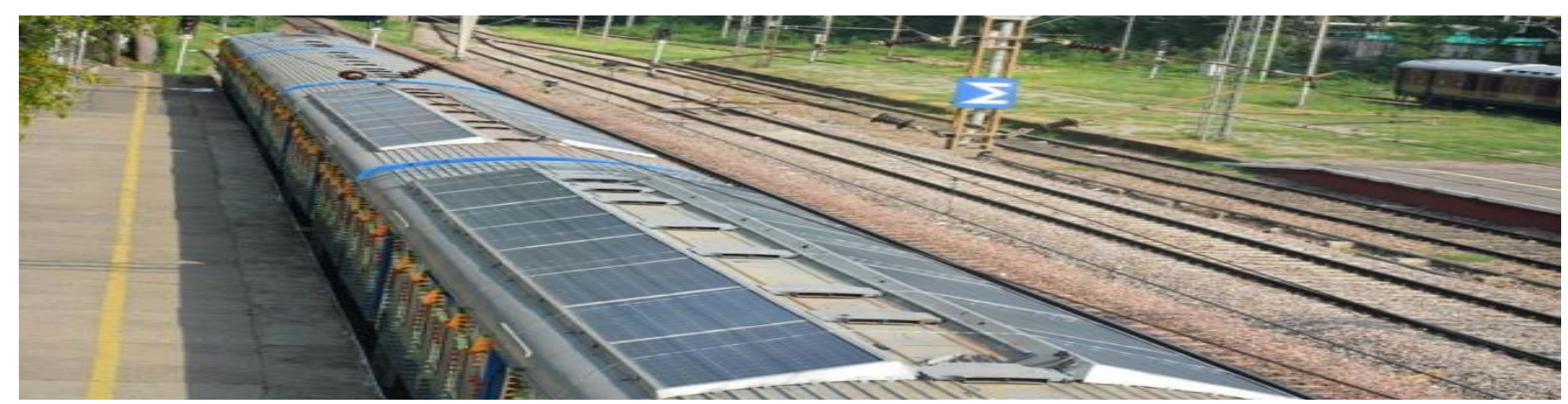

Photo 4. Using Solar Energy on the Railway - India

Source: http://ekolojist.net , 2017

Vehicles on which the solar energy is going to be used in the air transport have still been at the stage of designing. French designer Daphnis Fournier has been trying to design an environmentally friendly aircraft that makes air transportation more efficient with the project called "Ecological Aircraft Design Concept". With the concept of aircraft being designed, it is expected that the aircraft of the transporters will carry out their operations by spending less energy. (Habertürk, 2017).

\subsection{Storage}

The increasing efficiency of the solar panels along with the developing technology has been improving the storage of the generated electricity and its use in the facilities every other day. The solar panels used previously only for heating the water have reached the state of being able to operate all of the electrical appliances at homes. These developments encourage companies producing goods and services to use solar energy systems. Today, the warehouse enterprises offering logistics services are among the ones take advantage of the solar energy systems. (Knez et al., 2011). Although their number is not high yet, the warehouse facilities with the photovoltaic systems installed on their roofs meet all of their electrical needs in this way. It has been observed that the demand for the photovoltaic systems is much more especially in the cold air depots that consume more electricity. The depots shown in Figures $4 \mathrm{a}$ and $4 \mathrm{~b}$ can be given as examples of warehouses that provide logistic services and use solar energy. 


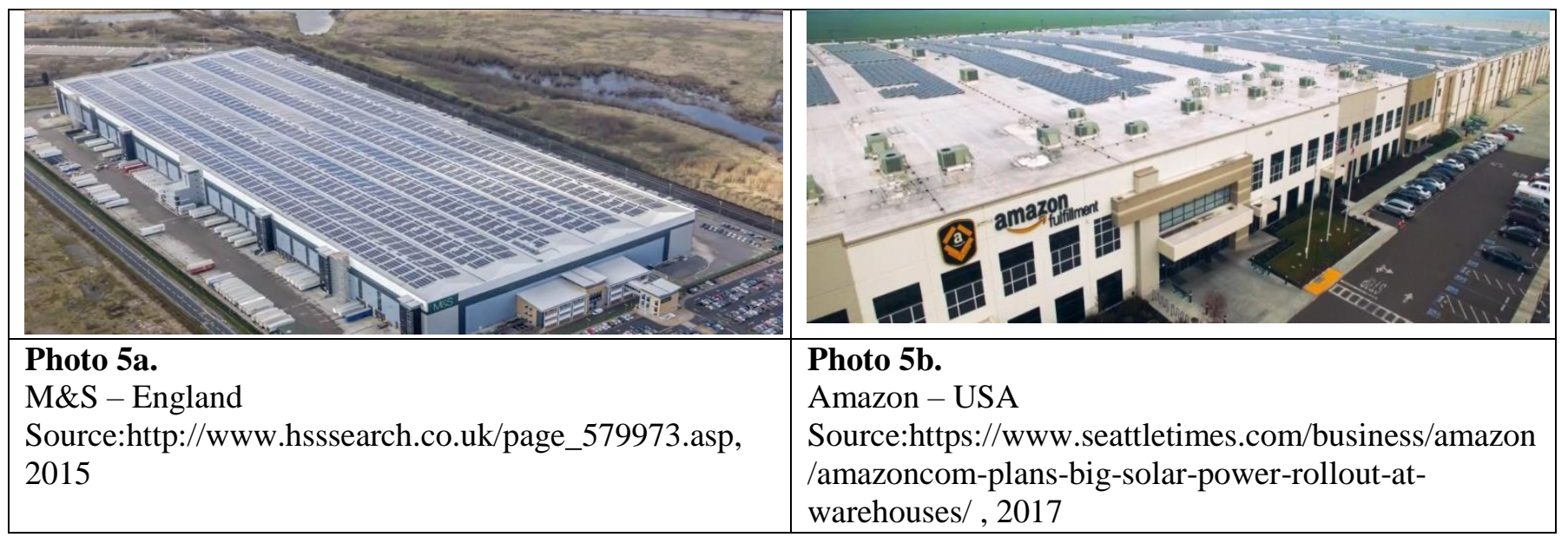

\subsection{Logistics Infrastructure}

Solar energy is also used in the scope of improving the infrastructure for providing logistics services along with the transportation and storage services. For example, the first solar-energy powered road called "Wattway" which is 1 $\mathrm{km}$ long has been constructed in the town called Tourouvre-au-Perche in the Normandy region. More than 2000 drivers in 2 years have tested the road covering an area of 100 square kilometers and costing 5.2 million dollars. It is stated that the road that can even operate the street lamps can also meet the electricity needs of a village with a population of 3400 at the same time. This region receives strong sunshine only 44 days per year. Wattway is shown in Picture 5 (Science and Techno, 2017).

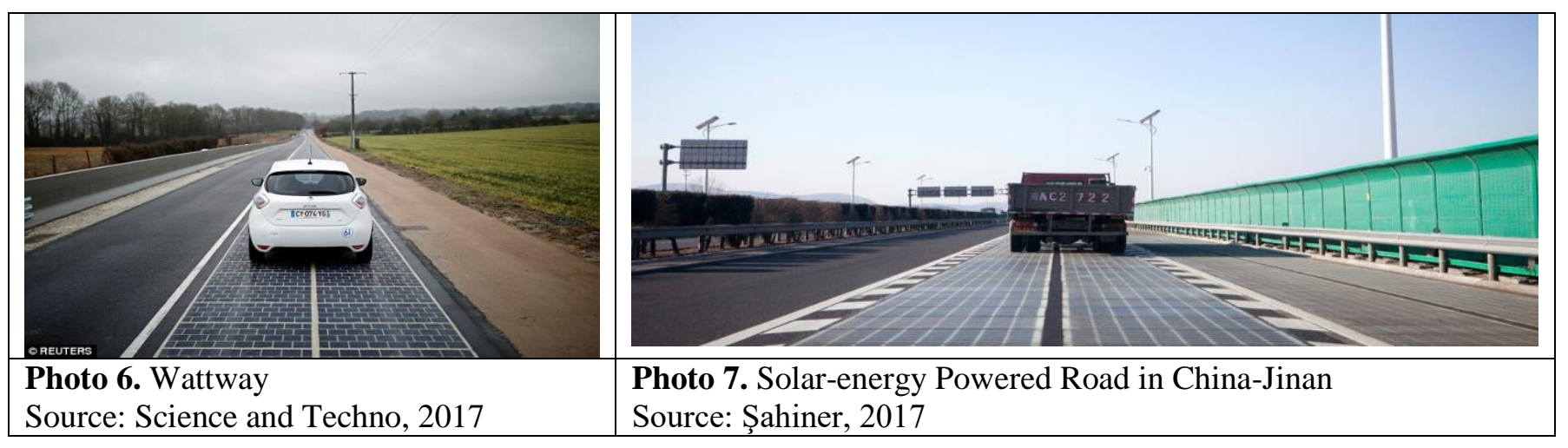

Another solar-energy powered road applications are seen in China. China, which makes a great number of its investments in renewable energy through solar energy, presents the solar-energy powered road seen in Photo 6. The 2-kilometer-long road built in the city of Jinan where around 7 million people live and is located at an important point for the transport network of China has been planned as it will initially generate electricity for the houses in its surroundings, and in the following years it will be able to directly charge the vehicles traveling on it along with the development of wireless charging technology for electric vehicles (Şahiner, 2017).

China has also been working on the first solar-powered super-highway to produce electricity through sunlight. The 100 -mile $(160 \mathrm{~km})$ long highway has been planned to connect three large cities in eastern China. This motorway is being built to be able to charge the electric cars and allow the drivers to continue to drive without stopping. The first part of the superhighway with a cost of 17.4 billion yuan ( 2 billion euros) is expected to be opened in 2021 . In the long term, it is stated that an intelligent traffic control system will be installed on the highway and vehicles and thus the autonomous vehicles can also be supported (Binay, 2018).

\section{Solar Energy in Logistics Sector in Turkey and Its Applications}

The use of solar energy in the logistics sector in Turkey is not as intensive as it is in developed countries. When it is evaluated in terms of services provided in the logistics sector, it is seen that it is preferred mostly in storage and warehouse services. 
Recently, the rising momentum of solar energy has started to attract the attention of logistic companies and warehouse operators, especially those having large roof areas, and the companies have started to use solar energy in their warehouses.

Although their numbers are low yet, the storage facilities that the photovoltaic systems have been installed on their roofs meet all of their electricity needs this way. It is seen that there is more demand for solar energy usage especially in cold storage depots that consume more electricity.

On the roofs of the storage and warehouse in the Samsunport port area of the Cey Group which launched an important project within the context of "Green Port" in 2018, the first solar energy power plant with the production capacity of 2MW constructed on the port area has started electricity generation in January (Solarist, 2018).

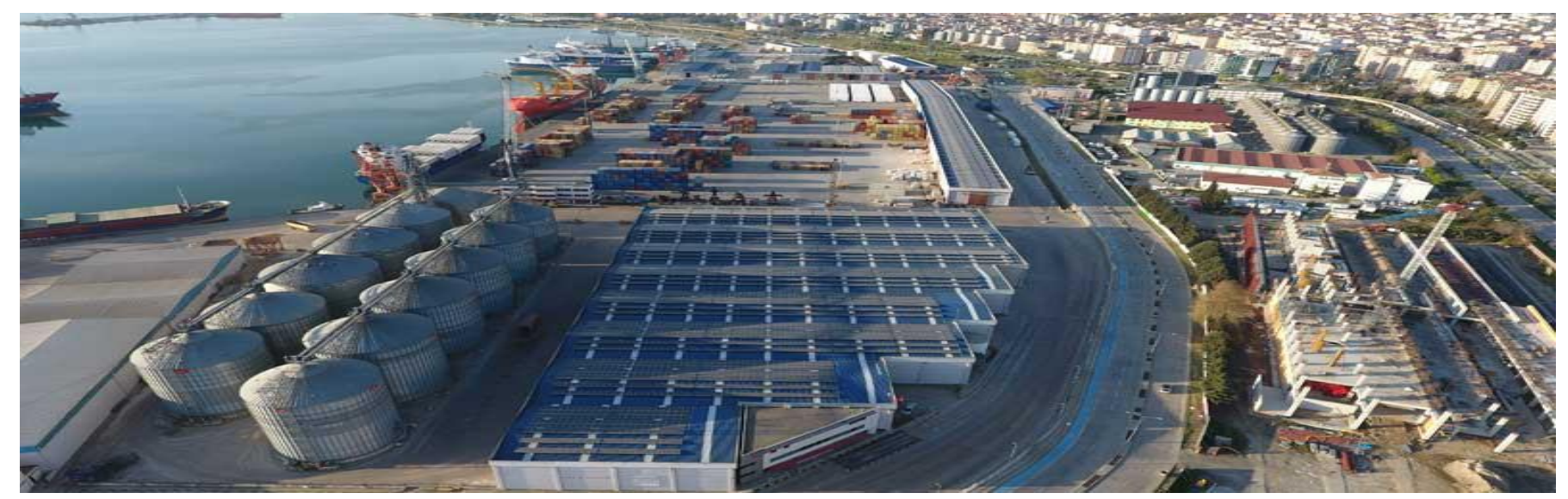

Photo 8. Cey Group Facilities - Samsun Port

Source: http://www.samsunport.com.tr, 2018

With the use of 8 thousand 448 units of monocrystal type solar panels with a high efficiency rate on the roof area of 23 thousand 500 square meters, it has been planned to actualize an electricity production of approximately 2 million 800 thousand $\mathrm{kWh}$ per year and a reduction of approximately 32 million $\mathrm{kg} \mathrm{CO} 2$ emissions in 30 years. It is aimed to contribute to the protection of the environment by using SES to generate electricity equivalent to the electricity need of approximately 2 thousand dwellings.

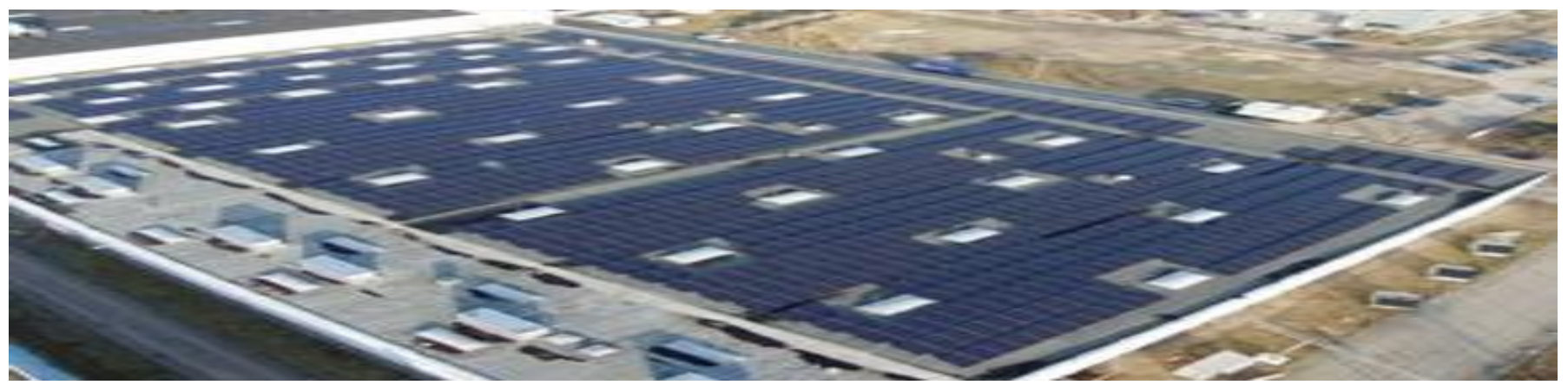

Photo 9. Reysaş Logistics Facilities - Torbalı

Source: http://www.reysas.com, 2018

One of the largest on-the-roof photovoltaic power plants installed by Reysaş Logistics on the roof of the warehouse in the town of Torbalı provides service with its production capacity of 840 kilowatts (Reysaş Logistics, 2014).

\section{Conclusion}

Renewable energy is the energy that can be obtained from the resources in nature and can be permanently supplemented by nature. Solar Energy is one of the most preferred systems on the issue of renewable energy resources since it is never consumed away. Solar energy is an environmentally clean resource of energy, natural materials are used, very economical, not dependent on external resources and every country can use. Countries such as Germany, Denmark, and Spain are the pioneers of solar energy generation and technology in Europe. Germany, which is on the path of becoming a global power, is an important country in this solar energy issue. In our country, 
the region that receives the highest solar energy is the South Eastern Anatolia Region, the Mediterranean Region follows this. The first thing that comes to mind in the generation of electricity from solar energy is the solar cells, namely the photovoltaic cells, that convert the sun rays into the form of electricity. Solar cells work based on the photovoltaic principle. That is, when the light falls on them, an electrical voltage is formed at their ends. The source of the electrical energy supplied by the cell is the solar energy coming onto its surface. Depending on the power demand, by connecting the modules to each other in series or parallel, a system is built from a few Watts to Megawatts.

The use of solar energy in the logistics sector in Turkey is not as intensive as it is in developed countries. When it is evaluated in terms of services provided in the logistics sector, it is seen that it is preferred mostly in storage and warehouse services. Recently, the rising momentum of solar energy has started to attract the attention of logistic companies and warehouse operators, especially of those having large roof areas, and the companies have started to use solar energy in their warehouses. Although their number is low yet, the warehouse facilities that the photovoltaic systems have been installed on the roofs meet all their electricity needs this way. It is seen that there is more demand for solar energy usage especially in the cold storage depots that consume more electricity.

\section{References}

Anonymous (2018a). Enerjinin Kullanım Alanları. http://enerjisistemleri.blogspot.com.tr/2010/12/resimgalerisi.html (Erişim tarihi: 13.10.2018).

Anonymous (2018b) . https://www.ultraenerji.com/yenilenebilir-enerji-2/yenilenebilir-enerji-neden-onemlidir.html (Erişim Tarihi: 10.10.2018).

Anonymous (2018c). https://www.enerji.gen.tr/dunyada-gunes-enerjisi.html (Erişim tarihi: 13.10.2018).

Anonymous (2018d) . http://www.ayetek.com/gunes-paneli-sistemleri-nedir/ (Erişim Tarihi: 10.10.2018).

Anonymous (2018e). http://www.solar-bazaar.com/menuis/igeme-yenilenebilir_enerjiler-teknolojileri..pdf (Erişim tarihi: 13.10.2018).

Bilim ve Tekno (2017). Dünyanın İlk Güneş Enerjili Yolu: Wattway, Erişim: https://www.bilimvetekno.com/dunyanin-ilk-gunes-enerjili-yolu-wattway/ , Erişim Tarihi: 20.10.2018)

Binay, O. (2018). Çin'den milyar dolarlık süper otoyol!, Milliyet Gazetesi - 01.03.2018, Erişim: http://www.milliyet.com.tr/cin-den-milyar-dolarlik-super-otomobil-2619125/, Erişim Tarihi: 02.10.2018)

Ekolojist (2017). Hindistan Güneş Enerjisi ile Çalışan Tren Üretti - 23.07.2017, Erişim: http://ekolojist.net/hindistan-gunes-enerjisi-ile-calisan-tren-uretti/ , Erişim Tarihi: 03.10.2018

Habertürk (2017). Güneş Enerjisi ile Çalışan Tren Seferlere Başlad1 - 20.07.2017, Erişim: https://www.haberturk.com/ekonomi/enerji/haber/1569858-hindistan-gunes-enerjisi-tren , Erişim Tarihi: 03.10.2018)

HSS (2015). M\&S Leads Way With Roof-Mounted Solar Power, Erişim: http://www.hsssearch.co.uk/page_579973.asp , Erişim Tarihi: 29.09.2018)

Karamanav, M. (2007). Güneş enerjisi ve güneş panelleri. Yüksek Lisans Tezi, SÜ Fen Bilimleri Enstitüsü, Elektronik Bilgisayar Eğitimi Anabilim Dalı, Sakarya.

Kargo Haber (2016). "Lojistik Depolarda Güneş Enerjisi Kullanımını Uzmanına Sorduk", http://www.kargohaber.com/lojistik-depolarda-gunes-enerjisi-kullanimini-uzmanina-sorduk-3791h.htm , (Erişim Tarihi: 12.10.2018)

Knez, M., Bajor, P., \& Seme, S. (2011). Green logistics - a solar warehouse concept. Logistics \& Sustainable Transport. Retrieved from https://dk.um.si/IzpisGradiva.php?lang=eng\&id=31028

MOL - Mitsui O.S.K. Lines (2012). World's First Hybrid Car Carrier Emerald Ace Completed - 29.07.2012, Erişim: https://www.mol.co.jp/en/pr/2012/12035.html, Erişim Tarihi: 05.10.2018.

NTV (2017). Tesla Semi, İlk Defa Yollarda - 18.11.2017, Erişim: https://www.ntv.com.tr/galeri/teknoloji/teslasemi-ilk-defa-yollarda,0kjbif0chEW6BtYpKzPC2w/tSRcavN8IE-PzesYMGyz4Q, Erişim: 05.10.2018.

Oluklulu, Ç. (2001). Güneş enerjisinden etkin olarak yararlanmada kullanılan fotovoltaik modüller, boyutlandırılmaları ve mimaride kullanım olanakları üzerine bir araştırma. Yüksek Lisans Tezi, GÜ Fen Bilimleri Enstitüsü, Mimarlık Anabilim Dalı, Ankara.

Özgöçmen, A. (2007). Güneş panelleri kullanarak elektrik üretimi. Yüksek Lisans Tezi, GÜ, Fen Bilimleri Enstitüsü, Elektrik-Elektronik Mühendisliği Anabilim Dalı, Ankara.

Öztürk, H. (2008b). Güneş enerjisi ve uygulamaları. Birsen Yayınevi, İstanbul, 277 s.

Öztürk, H.H., Kaya, D (2013). Güneş enerjisinden elektrik üretimi: Fotovoltaik teknoloji. Umuttepe Yayınları, Kocaeli, $417 \mathrm{~s}$

Reysaş Lojistik (2014). Yeşil Lojistikçiler Röportaj1., http://www.reysas.com/uploads/yesil-lojistikciler-sitesinde- 
24temmuz2014-de-yayinlanan-roportajx_1451916342.pdf , Erişim Tarihi: 16.10.2018

Solarist (2018). Ceynak'da Tüm Tesisler Elektriği Güneşten Alacak. Erişim: https://www.solar.ist/ceynakta-tumtesisler-elektrigi-gunesten-alacak/, Erişim Tarihi: 29.09.2018

Şahiner, Seda G. (2017). Çin "Güneş Enerjili” Otoyolunu Yakında Hizmete Açacak", Webrazzi Köşe Yazıs1 25.12.2017, Erişim: https://webrazzi.com/2017/12/25/cin-gunes-enerjili-otoyolunu-yakinda-halka-acacak/ , Erişim tarihi: 26.10 .2018$.

Taşıyanlar (2017). Yeni Dünyanın Yolu Güneşe Doğru - 27.12.2017 , Erişim: http://www.tasiyanlar.com/haber/13037-yenilenebilir-hareket-yeni-dunyanin-yolu-gunese-dogru.html , Erişim Tarihi: 04.10.2018.

YEGM, (2018). Yenilenebilir enerji genel müdürlüğü, http://www.yegm.gov.tr/MyCalculator/Default.aspx , Erişim tarihi: 11.10 .2018 . 
